MEMÓRIA

\title{
Recommendations for the CTA Law (Plano Smith) e Brasil: futura potência aérea Conferência Proferida pelo Professor Richard H. Smith, no Rio de Janeiro, em 1945
}

ApresentAÇÃO

Michal Gartenkraut*

Muito oportuna a iniciativa da $R B I$ de publicar dois importantes documentos ${ }^{1}$ que fundamentaram o desenvolvimento do setor aeroespacial no Brasil. O convite para comentar os documentos em tela oferece oportunidade ímpar para abordar, ainda que de forma muito resumida, pedaços dessa extraordinária epopéia, até hoje ainda pouco difundida entre o grande público.

Por limitação de espaço, não me deterei na análise detalhada dos textos. Gostaria, sim, de ressaltar aspectos e elementos importantes que, a meu ver, constituíram os fatores principais de sucesso da ambiciosa empreitada.

De fato, a importância dos documentos pode ser observada - e admirada - sob vários ângulos. O primeiro, pelo seu valor histórico. Trata-se do registro formal do início de um dos mais importantes experimentos em política industrial, tecnológica e educacional no país. O segundo, pelo seu conteúdo conceitual, evidenciando extraordinária competência técnica. $\mathrm{O}$ terceiro,

\footnotetext{
* Engenheiro mecânico formado pelo ITA (1969); reitor do ITA de 2001 a 2005. Ocupou diversos cargos no governo federal, entre os quais os de superintendente e presidente do IPEA e secretário geral do Ministério do Planejamento. Atualmente exerce o cargo de presidente-executivo da Fundação Nacional da Qualidade.

1 Esta publicação inclui apenas parte do primeiro documento. O texto completo bem como a conferência do professor Smith podem ser consultados na página da RBI, no sítio da FINEP: <www.finep.gov.br>. (N. do E.)
} 
pela ambiciosa visão estratégica e uma enorme coragem para inovar de seus formuladores: enxergar as chances futuras de um pólo educacional-tecnológicoindustrial no campo aeroespacial no Brasil, nas precárias condições prevalecentes em meados do século passado, que, como sabemos, se tornou um caso mundial de sucesso; e mais, iniciar o projeto com a criação de uma escola singular de educação e ensino superior, absolutamente fora dos padrôes vigentes à época. Finalmente, o quarto, pelos resultados produzidos nestes mais de 50 anos: a formação de uma massa crítica de recursos humanos altamente sofisticados, nos campos de interesse da aviação, capaz de aprender e educar, de pesquisar e desenvolver e, finalmente, de produzir aviōes e comercializálos de modo competitivo.

Outro aspecto do Plano Smith que merece ser ressaltado é o caráter altamente avançado das inovações organizacionais sugeridas para o modelo de gestão da nova entidade. Diria até que o grau de engenhosidade de algumas das propostas é avançado até para os dias de hoje, quem diria para aqueles idos da década de 1940. Por essa razão, embora o plano tenha sido aprovado, algumas de suas proposições não chegaram a ser implementadas. Este é certamente o caso da criativa proposta de um modelo dual civil/militar, autoconversível, isto é, o CTA seria uma entidade totalmente civil em tempo de paz, convertendo-se automaticamente em uma organização militar em tempo de guerra (lembrar que estávamos apenas alguns poucos anos após o fim da segunda conflagração mundial). Outro aspecto inovador, mas igualmente ousado demais para a época, é o de uma entidade auto-sustentável financeiramente, requisito considerado essencial tendo em vista a escassez de recursos do Tesouro Nacional e o reconhecimento da existência de outras fontes de financiamento do empreendimento.

A autoria dos textos é do professor Richard H. Smith, na época o chefe do Departamento de Engenharia Aeronáutica do Massachusetts Institute of Technology, o lendário MIT, em Boston, EUA. Uma das maiores autoridades mundiais em assuntos de aviação e engenharia aeronáutica, seu envolvimento no projeto brasileiro reflete bem o alcance da ambição do pequeno grupo, liderado por um jovem oficial da Aeronáutica, o tenente-coronel Casimiro Montenegro Filho, responsável pela visão e pelas idéias básicas iniciais do empreendimento. 
Oficial aviador respeitado, pioneiro do Correio Aéreo Nacional, Montenegro era engenheiro militar com especialização em engenharia aeronáutica, formado pela Escola Técnica do Exército (atual IME), no Rio de Janeiro. Criado o Ministério da Aeronáutica, em 1941, Montenegro transfere-se para a Força Aérea Brasileira e inicia estudos e ações para tornar realidade a sua concepção de verdadeira soberania: ser o país capaz de dominar o ciclo completo da tecnologia aeronáutica.

Certo de que necessitava de respaldo técnico de peso para o seu projeto, Montenegro visitou Smith em Boston, antes do final da Segunda Guerra Mundial, expondo suas idéias e convidando-o a colaborar. A destacar, nesse contato, o papel fundamental de dois assessores de Montenegro (e que viriam a acompanhá-lo ao longo de muitos anos): o major Oswaldo Nascimento Leal e o engenheiro Arthur Soares Amorim, que, tendo estudado no MIT, sugeriram não só a visita a Smith, mas também a eleição daquele famoso instituto como modelo para a concretização do sonho de se ter no Brasil uma instituição de ensino e pesquisa de primeira linha, como o primeiro passo para se chegar à implantação de uma indústria em setor de tecnologia de ponta.

$\mathrm{O}$ apoio de Smith foi integral e entusiástico. De início, ele se dispôs a vir ao Brasil e fazer uma palestra sobre os desenvolvimentos recentes e as perspectivas da aviação. Assim, em 1945, no auditório do Ministério da Educação, no Rio, ele profere uma conferência histórica, cuja transcrição corresponde a um dos documentos agora disponíveis aos leitores da $R B I$. A leitura do documento confirma a inequívoca abrangência do conhecimento de Smith sobre a matéria. A ressaltar, como lição para os dias atuais, principalmente considerando as circunstâncias da época, a sua recomendação sobre a não-conveniência da aquisição de aeronaves dos Estados Unidos - "nem que fossem oferecidos de graça, pois isso iria atrasar o desenvolvimento da indústria aeronáutica brasileira”. Eis uma lição - de mais de 50 anos atrás! - para o falso dilema entre comprar ou fazer, que até hoje dilacera o debate de política industrial em nosso país. É também uma das primeiras apostas, de peso mundial, no futuro do Brasil como potência mundial no campo da aviação.

Aproveitando as reações positivas de sua conferência no Rio, por iniciativa de Montenegro, Richard Smith foi contratado como consultor por seis meses pelo Ministério da Aeronáutica, para preparar os estudos do que viria 
a ser o projeto do Centro Técnico de Aeronáutica, iniciando, com a criação do Instituto Tecnológico de Aeronáutica, a escola singular que constitui o berço do moderno complexo científico-tecnológico-industrial aeroespacial tal como o conhecemos hoje. O resultado desse trabalho de Smith é o outro texto aqui reproduzido.

Terminado o trabalho de consultoria, Smith foi convidado a permanecer no Brasil, acompanhando a implementação do plano, tornando-se o primeiro reitor do ITA.

Embora a autoria e o mérito do documento pertençam inegavelmente a Smith - razão pela qual também é conhecido como Plano Smith -, torna-se necessário sublinhar que muito do que ali está exposto reflete também a visão e as idéias de Montenegro e seus companheiros. Talvez o maior mérito de Smith tenha sido, além do aval de seu nome, a correta inserção dos pensamentos de Montenegro e seu grupo no que havia de melhor no contexto acadêmico e industrial da época. $\mathrm{E}$ a tenacidade com que lutou para defender os eixos principais do projeto: a necessidade de a escola estar fora do alcance da burocracia do Ministério da Educação; a necessidade de completar a formação básica dos alunos, incompleta no ensino fundamental e médio brasileiro, em sua avaliação (daí a expressão na lei que define o ITA, "uma instituição de educação e ensino superior”, premissa válida até hoje); a necessidade de total autonomia da escola em termos acadêmicos e administrativos. Convenhamos: uma tarefa hercúlea que só foi vitoriosa pelo apoio incondicional proporcionado por Montenegro, o primeiro diretor do CTA.

Assim, em 1950 (data de transferência de suas instalações precárias do Rio para as atuais, em São José dos Campos) nascia o ITA, como núcleo inicial do CTA e berço da indústria aeronáutica por nascer, e sob o signo da inovação: autonomia em relação ao esclerosado sistema educacional da época; autonomia em relação ao Ministério da Aeronáutica; sistema departamental, currículo aprovado anualmente pela congregação, alunos e professores residentes em tempo integral em um campus integrando atividades de educação, de ensino de graduação e pós-graduação, de pesquisa pura e aplicada.

A excepcional qualidade do projeto Smith-Montenegro é sem dúvida um dos fatores responsáveis pelo sucesso do empreendimento. Mas sua repercussão vai muito além. Experimentadas com sucesso no ITA, a maioria das 
inovações educacionais ali introduzidas, revolucionárias para a época, estabeleceram os fundamentos para as reformas de todo o sistema educacional brasileiro, iniciado, sobretudo, com a edição da Lei de Diretrizes Básicas da Educação, de 1962.

Consta, segundo a história oral passada de geração a geração, que, ao apresentar esse plano ao presidente Getúlio Vargas, Montenegro teria sido questionado se não seria mais barato enviar os alunos ao MIT (de fato, seria). Não há registro da resposta dada por Montenegro, mas, considerando o resultado (o plano foi aprovado), é plausível imaginar que ele, enquanto concordava com o cálculo frio na ponta do lápis, teria argumentado que daquela maneira não se poderia assegurar a formação de uma massa crítica de engenheiros e cientistas educada na realidade brasileira e dedicada à criação e sustentação de uma indústria aeronáutica nacional e competitiva. Em apoio a essa hipótese, destaca-se a excelente exposição no plano e na conferência, na qual o professor Smith elabora com admirável visão as vantagens competitivas do Brasil para explorar um importante nicho na fabricação de aeronaves, a saber, aviōes mais econômicos (mais leves e mais baratos) - exatamente o espaço que meio século mais tarde a Embraer veio a ocupar. 


\section{Recommendations for the CTA Law}

\section{Foreword}

Brazil will be the first major country of the world to integrate all educational and research facilities of a nation, in all fields which pertain to aeronautics at the professional level, both civil and military, in one geographical center and in one legal organization. Not only will Brazil be the first nation to centralize these facilities but she will also be the first nation to plan these facilities, before they are created and started, as properly correlated components of a single organization.

While the future benefits which will result from geographic centralization and organic integration of these facilities in Brazil will be great, the problem of forming the legal structure of such an institution so that centralization will yield the maximum benefits in increased effectiveness and economy, in all of the component parts of the institution, and in all degrees of national strain from calm peace to hot war, is not easily resolved.

To the organizational problem of full centralization must be added the organizational problem of providing adequately for future expansion in the allied professional fields, especially to include mechanical and electrical and possibly civil engineering.

And to these organizational problems should be added the problem of adequate and efficient financing.

In recommending to the Brazilian congress the correct kind of basic law for the CTA, the Air Ministry therefore faces not only an important problem but also a unique problem without precedent, in institutional organization. Such a law must be short and general. But such laws are the most difficult kind to draft wisely because they necessarily carry broad powers which cannot be requested or obtained until one knows what powers are necessary and why 
they are necessary and until one knows what he will do with these powers after they are granted.

First it is necessary to study the best and most successful research and educational institutions abroad and the best adaptation for Brazil. From these studies the most favorable legal status and institutional form for the Brazilian CTA become clear. This study is made in Part I.

Second it is necessary, since the institution will have a new form, to set up the main regulations and policies under which an institution having this status and this form would actually function. From these regulations and policies the minimum broad powers which must be given in the basic CTA law become clear. This study is made in Part II.

From these two studies the form of basic CTA law can be drawn with relative ease. This is done in Part III. ${ }^{1}$

\section{Part II}

\section{Basic Policy and Organic Form of the CTA Under the CTA Law, Based on the Experience of Forcian Countries and on the Particular Condi- tions In Brazil}

A study of the pioneering problem in institutional organization which Brazil faces in setting up the CTA in the light of Brazilian condition on the one hand and of the experience of foreign countries on the other, see Part I, leads clearly to a Brazilian adaptation of the German K.W.G. or the American RAND type of private, non-profit foundation. As adaptation of this kind of organization to the more comprehensive group of institutes and supporting services of the CTA, leads in turn to the following legal status and organic structure for the Brazilian CTA, which are summarized in the recommendations for the CTA law in Part III, and to the basic principles and policies which should subsequently be protected in the CTA Regulations which are given in Part II.

\footnotetext{
1 Por razões de espaço, não estão incluídas nesta publicação as partes I e III do documento original, nem os apêndices e a conferência do professor R. H. Smith, com exceção de duas figuras centrais ao entendimento do texto. A íntegra do documento pode ser consultada na página da revista no sítio <www.finep.gov.br $>$.
} 
A - Legal status, organic structure, administration and powers of the CTA.

I - Legal Status of the CTA and powers of its Board.

a. The CTA should be established by law as a private, independent, nonprofit, educational and research foundation, see item C-I-b, below, also Part I and Appendix II.

1. This form gives the maximum degree of decentralization of federal control, (see Part I), consistent with federal coverage of the "basic" budgets of the organization.

2. This form permits the CTA to accept grants, endowments and aids from the public.

(a) Endowment gifts under which private capital can be put to public service under private management should be encouraged in Brazil, especially in the field of higher education.

3. The CTA would be supported under the dual budget system, (see below), under which the federal government would be responsible only for the "basic part" see item A-III.

4. The federal government would transfer the legal ownership of the CTA to the CTA foundation.

b. The legal powers of the CTA should be vested in the CTA Board of Governors, hereafter called the Board.

1. The suggested membership of the Board.

(a) One air minister appointee,

(b) One Estado Maior of the armed forces appointee,

(c) One Air Staff appointee,

(d) President of the Civilian Conselho,

(e) President of the Military Conselho (in time of war),

(f) The following five civilian members at large appointed by the (a) - (d) members above and subject to unseating by the Air Minister during a war.

[1] One appointee representing industry, 
[2] One appointee representing commerce,

[3] One appointee representing education,

[4] One appointee representing research,

[5] One appointee from the federal administration.

2. All Board members should serve four year terms unless their terms are terminated by the Air minister because of a national emergency.

3. Legal powers of the Board.

(a) Power to own, acquire and receive public and private property, equipment and grants in any form.

(b) Power to appoint the director general of the CTA,

(c) Power to appoint the six members of the civil conselho,

(d) Power to appoint the six members of the military conselho, [1] After the air minister has dropped some or all of the civilian Board members at large, if he decides to do so.

[2] Subject to the confirmation of the air minister.

(e) Graduated administrative powers over the several CTA institutes and services as described in detail in appendix II and Figures 1 and 3.

(f) All the normal powers of a private, non-profit educational and research foundation.

c. Reason for recommending the legal flexibility in the membership and in the administrative powers of the CTA Board.

1. The main need for legal flexibility in the membership of the CTA Board is to permit the militarization of the IMAC and of the CTA in times of national emergency without destroying the legal independence of the CTA as a private institution and therefore without destroying the whole civilian end of the CTA, particularly the ITA for education and fundamental research. Since the full militarization of the large common laboratory and military institute and of the CTA is inevitable in time of war, it is far wiser to provide for it legally, since the same legal provision which gives war control would require a return to a civilian peace time status at termination and thus prevent permanent militarization. See the foreword to appendix II. 
2. The purpose of giving the CTA Board, in addition to its regular powers, see items I of Appendix II, the graduated administrative powers over the various parts of the CTA recommended under item II of Appendix II, is clearly explained in the foreword of Part III. A second objective is:

(a) To provide at the CTA a full spread of the degrees of centralization under a single private organization of effective federal control over the various parts of the CTA, varying from zero over the ITA end of the CTA, in times of peace or war, to a degree at the IMAC end which may vary from high control to full military control, depending upon the urgency of the times. If this flexibility is provided:

[1] Brazil would then be in good alignment, at least in the fields of professional aeronautics, with the best experiences of the strong air powers of the North.

[2] Brazil would have in the CTA an organization which is broad and flexible enough to embrace the whole U.S.A. system of educational and research institutions for both the military and civilian interests in aeronautics at the professional level, except for such colossal organizations as the Atomic Energy Commission, see the section on the U.S.A. in Part I.

d. The basic CTA law should specify in general terms that the graduated degrees of corporate administrative powers which are discussed under item $\mathrm{C}$ above and which are recommended in detail under items II in appendix II, must be delegated by the CTA Board to the Director General who is appointed by the Board from the government members of the Board. The CTA regulations, under the law, should require further that the Director General exercise these powers as a full time executive in residence at the CTA.

e. The CTA law should automatically terminate the war Board and require the reseating of a peace Board upon the legal termination of the national emergency. 
$f$. To emphasize the Board right which was recommended in item A-I-b3-(a) above, the CTA legal status and basic law should permit the Board to receive private and public gifts in the form of funds for new buildings or facilities, or endowments, or grants for specific purposes, or memorial funds for scholarships for foreign study or research, or in any other form, without affecting the obligation of the federal government to meet the basic budgets of the CTA.

1. The practice, common in northern countries, of wealthy men placing private capital in public service under private management, which has made the large foundations, universities, technical schools and hospitals in these countries possible, should be encouraged in Brazil.

2. This provision in addition to the dual budget system recommended below, would give the CTA the soundest possible financial structure and stability and in future years would add very greatly to the effective service of the CTA to the nation.

\section{II - Discontinuous board powers exercised directly at Board meetings.}

a. The regulations under the CTA law should specify that the CTA Board shall exercise direct decision powers only at stated meeting of the Board, over such matters as:

(a) Approving the basic budgets of the CTA.

(b) Approving the appointment, status, title and salary of the personnel which are included in the basic budgets.

(c) Approving major areas of activity of the CTA.

(d) Approving as projects in public relations, catalogues, publications, and similar releases through the mails and major projects in public relations generally.

(e) Appointing institute directors and confirming institute administrations.

(f) Granting ITA degrees and other certificates.

(g) Accepting and administering public and private gifts to the CTA.

b. Continuous board powers exercised by delegation to the Director General of the CTA, see item I-C-2 above: 
1. The basic CTA law should require the Board to exercise continuously by delegated powers to the Director General the additional graduated administrative powers listed under items II in appendix II, under a lower centralization of control during times of peace and under a higher centralization of control during times of war.

(a) The Board should, by law, exercise no continuous administrative powers over the ITA end of the CTA, see Figures 1 and 3 in time of peace or war, see also item A-II of appendix II.

[1] This provision would leave the ITA under a straight board reitor - corpo docente organization which is necessary for effective education and fundamental research. The education and fundamental research and of the CTA would then be 100\% decentralized from direct federal control, see Part I.

(b) The Board should, by law, exercise high continuous administrative powers in times of peace and complete military powers (if the government elects) in times of war, over the IMAC end of the CTA, see Figures 1 and 3, where the degree of federal control must be high, see item E-II of appendix II and the foreword of appendix II.

2. The CTA regulations under the CTA law, should state specifically the administrative powers which the Board must delegate to the Director General. The powers of administration over the component parts of the CTA are recommended under items II of appendix II. These powers would give:

(a) The federal government the correct graduated (effectual) control over the various parts of the CTA, through administrative powers delegated to the Director General.

(b) The CTA the full legal benefits of complete corporate independence and the high degree of decentralization from (direct) federal control, which must be provided for successful operation at the ITA end, see Part I and Figure 1 and 3.

c. After deducting the powers under $\mathrm{a}$ and $\mathrm{b}$ above all remaining administrative responsibilities and powers over the several institutes and groups of services at the CTA should, under the CTA regulations, be carried by the respective directors and their administrative staffs, see Figure 3. 


\section{III - The CTA Dual Budget and Endowment System of Financial Support}

a. The CTA can be supported best, as a private institution supported from federal funds and operated under a high degree of decentralization, under the dual budget system augmented by private and public gifts, under which:

1. The basic budgets of the various institutes and services groups, covering permanent personnel, maintenance, new construction and in one or two cases new acquisitions, are:

(a) Supplied in block appropriation form by the federal government through the Air Minister.

(b) Accounted and disbursed by the CTA Board which:

[1] Would delegate this power to the Director General.

(c) Subject to normal government regulations and scrutiny over global appropriations.

2. The supplementary budgets of the various institutes and groups of supporting services, covering temporary personnel, purchase of supplies, materials and equipment, repair and replacement of facilities and miscellaneous expenses incident to rendering research and other services, are:

(a) Supplied by revenues for services rendered and from research and development contracts with the CTA institutes.

(b) Spent, in the case of institute contracts for research and development, by the department head in whose department the research or development contract was carried out, and on the authority of the department head.

(c) Spent by the committee or the director in charge in the case of the various CTA supporting services.

(d) Held for accounting under the charge of the finance officer of the institute or of the part of the CTA concerned.

b. Under the dual budget system the official budget of the CTA would be the total of the basic budgets only. The supplementary budgets would not appear in this total. The political advantage of being able to present 
to the government an official budget which normally is much less than the total operating budgets of the CTA will be very important.

c. The private status recommended for the CTA would permit the CTA Board to receive and administer private and public gifts as explained in detail under item A-I-f above. This source of capital assets should supply a large part of the capital assets of the ITA in the years to come.

\section{B - The CTA Conselhos:}

\section{I - The Civil Conselho:}

a. Membership of the civil Conselho:

1. Six members should be chosen by the Board, on three year terms, from industry, air commerce, and the national administration:

(a) The president of the civil conselho must be chosen from the conselho membership by the conselho.

(b) The president of the civil conselho will be an ex-officio member of the Board. (See Fig. 1).

2. Functions of the civil conselho.

(a) To advise the Board on scientific, industrial, commercial, technical and professional matters.

(b) To sponsor national forums for the discussion of the aeronautical problems of Brazil.

3. Powers of the civil conselho:

(a) The civil conselho should, by law, have no powers inherent or by delegation.

(b) The president of the civil conselho would have the normal powers of membership on the Board.

4. Budgets:

(a) Membership on the civil conselho would carry no salary or travel expense allowances.

(b) The civil conselho, through its president, would by law present to the Board a small basic budget to cover the printing and incidental expenses connected with conducting the national forums which, under 2 (b) above, are sponsored by the civil conselho. 
b. The Military Conselho.

1. During periods of national emergency only, the Board (with or without its five civilian members at large as the Estado Maior selects) must on the request of the Estado Maior of the Armed Forces choose a military conselho.

2. Membership of the military conselho.

(a) Six members should be chosen by the Board for the period of the national emergency, and confirmed by the Estado Maior.

(b) The president of the military conselho must be chosen from the conselho membership by the conselho.

(c) The president of the military conselho will be an ex-officio member of the Board during the emergency (see Figure 1).

3. Functions of the military conselho.

(a) To advise the Board on general defense problems in which the CTA can assist, such as:

[1] Accelerated war curricula at the ITA.

[2] Accelerated growth of the CTA research and development facilities.

[3] War research and development.

4. Powers of the military conselho.

(a) The military conselho should have no powers inherent or by delegation.

(b) The president of the military conselho would have the normal powers of membership on the Board during the emergency period.

5. Budget.

(a) The military conselho would have no budget.

c. The reasons for recommending a military conselho.

1. An institution as important as the CTA would be in case of war in order to be fully effective in the war effort should be under the administrative and advisory direction of more than four government members of the Board. (see A-I-b). 
2. A CTA Board of five members, four officers and one civilian, is large enough for war service and small enough for high war efficiency and quick action.

3. The military conselho in time of war would:

(a) Increase the number of government men in administrative and advisory duty at the CTA from three to nine and thus would satisfy item 1 above.

(b) Leave the CTA under a war Board of only five members which satisfies item 2 above.

(c) Avoid the important danger of sudden changes in basic policy at the CTA. If six military men should suddenly replace the six civilian members on the Board, the large majority of new, uniformed government members could inaugurate drastic and sudden changes in CTA policy which could do irreparable harm. The danger of this should be avoided.

(d) Facilitate the legal transition from a war Board at the termination of the emergency. It would be ten times easier to unseat one military man from the CTA Board than six.

C - The Component Parts of the CTA classified under the Degrees of Effective Federal Control over their Administrations.

\section{I - The ITA for education and fundamental research.}

a. Degree of effective federal control, see appendix II.

1. Zero in times of peace or war, see Figure 1 and 3.

$b$. The CTA law in specific terms should give the ITA a normal, fully decentralized, board-reitor-corpo docente organization, with no direct continuous administrative federal control.

1. This would give the ITA end of the CTA organization for education and fundamental research both the standard organization which is used successfully in hundreds of American universities and technical institutes and the degree of decentralization of control which gives the most effective and economic operation of a fundamental research organization, see section E below and the section on Germany in Part I. 
2. This degree of decentralization of federal control over the ITA end of the CTA requires that the CTA itself be fully decentralized from direct federal control, see item A-I-a, above.

c. The CTA law, in specific terms, should also require that the ITA for education and fundamental research consist of:

1. An Escola Fundamental for the basic physical sciences and their associated disciplines.

2. An Escola Profissional for all of the main professional specialization in science and engineering upon which aeronautics depends for professional men and research.

(a)Including a graduate school leading to higher degrees including the doctorate.

$d$. The CTA regulations under the CTA law should contain the items on basic educational and fundamental research policy which are given in sections $\mathrm{D}$ and $\mathrm{E}$ below.

e. The CTA regulations under the CTA law also should:

1. Require the CTA Board to inform the reitor on

(a) The maximum basic budget which the Board can recommend for the ITA,

(b) The maximum enrollment at the ITA which the basic budget can support.

2. Require the ITA reitor to present to the Board annually:

(a) The basic budgets of the ITA, item A-III-a-1, above,

(b) The ITA annual report and recommendations.

II - The committee administered CTA services which are maintained chiefly for the ITA, including the CTA library, the CTA theater and the CTA athletic facilities:

a. Degree of effective federal control, see appendix II

1. Very low in times of peace or war, see Figure 1 and 3. 
b. The CTA law in general terms, see item A-III Part III, should permit only the lowest degree of federal control over these and similar CTA committee administered services, because these services are closely allied to the ITA and would never need, even in time of war, to be administered under strong control by the government.

1. The degree of effective federal control which is recommended, for inclusion in the CTA regulation, is the control which the director general would normally exert as chairman of the respective committees. See item A-I-d above and Figures 1 and 3, also item B-II of appendix II. The small flexibility which the government might need in this control in times of war could be exerted easily by the chairman without extra powers.

c. The CTA regulations under the CTA law should also:

1. Fix the membership of each of these committees of seven members, six in addition to the director general, and specify that the six members at large be appointed by the institute directors from the staffs of the institutes roughly in proportion to the size of their basic budgets.

2. Require the CTA Board to inform the several committees on:

(a) The maximum basic budget which the Board can recommend for the support of their work,

(b) The maximum acquisitions which the basic budget can support,

3. Require the committees in each case to present to the CTA Board annually:

(a) The basic budget of the particular service including in the case of the CTA library new acquisitions,

(b) The committee annual report and recommendations.

4. Require the committee of those services which involve current receipts and expenditures, the CTA theater for example, to keep supplementary budgets which are under the control of the committee but which are open to inspection by the Board, see item A-III-a-2 above. 
III - The civilian institute (or later institutes) of research and development, see Figure 1:

a. Degree of effective federal control, see appendix II:

1. Low in times of peace to high in times of war, depending upon the need, through the control of the director general over research and development contracts, see item C-II-b of appendix II, and Figure 3.

$b$. The CTA law, in specific terms, should require the CTA Board to create and activate the first civilian research and development institute within a period of three years after the enactment of the CTA law, whose function would be:

1. To meet the civilian needs of the Brazilian government, industry and airlines for professional assistance and cooperation in both the industrial and commercial fields of aeronautics, in the equivalent way that the NACA and AEDC research centers meet the needs in the industrial field and that the CAA research center in Indianapolis meets the needs in the airline operations field in the U.S.A.;

(a) The CTA law should specifically permit the Board, when the need and opportunity arise, to divide the CTA civilian institute of research and development into two coordinated research and development institutes, one for industry, called the IIAC in Figures 1 and 3, and other for air commerce, called the ICAC in these figures.

2. To assume responsibility for promoting the aircraft and the aircraft accessories industries in Brazil, and for promoting the development, modernization, safety and economic soundness of Brazilian commercial aviation.

c. The reason for recommending the three year limit in the basic CTA law on the creation of the first civilian research institute:

1. To require the CTA Board to take early action in providing Brazil with adequate facilities for meeting its many critical problems in industrial and commercial aviation before these unsolved problems cause an economic and technical collapse of Brazilian commercial aviation: 
(a) For example Brazil's DC-3's will all have to be replaced with other equipment in the next few years. This alone will precipitate a very important and very critical economic problem for Brazil.

(b) Similarly Brazil's DC-3's in the meantime must be maintained more and more from spare parts made in Brazil. The promotion of auxiliary industries in Brazil for the production of DC-3 spare parts is another critical problem.

(c) Also there are numerous problems in air commerce which are growing more critical not only because of (a) and (b) above but also because the national airlines of Brazil must see inaugurate night flying. Both new equipment and night flying will impose greater demands on airports and on traffic control systems. The CTA must take the initiative in solving these problems and do it very soon.

d. The CTA regulations under the CTA law should require:

1. The CTA Board to inform the institute director (or directors if there are two institutes) on:

(a) The maximum basic budget which the Board can recommend for the institute,

(b) The maximum new construction and new equipment the basic budget can support.

2. The institute director (or directors) to present to the Board annually:

(a) The basic budget of the institute,

(b) The institute annual report and recommendations.

3. The institute director (or directors) to maintain their own supplementary budgets for receipts and expenditures under the institute contracts for research and development and to permit their inspection by the Board.

e. The CTA regulations should contain the recommendations on the basic principles and policy of CTA research and development given in section $\mathrm{D}$ below. 
$f$. The delegation of the specific administrative powers of the Board ever the civilian institute (or institutes), which are listed in C-II of appendix II, to the director general of the CTA with instructions to modulate these powers from low in times of peace to high in times of war, depending upon need.

1. Abuse of administrative powers delegated by the Board to the director general, under specific CTA regulations, should be made sufficient grounds for unseating, see item A-I-b-3 above.

IV - The large common laboratories, the airport and its industrial facilities and the common CTA general services.

a. Degree of effective federal control, see appendix II,

1. Medium in times of peace to virtually full military in times of war, depending upon the need through a modulation of the director general's control over items a, b, c, and d of D-II in appendix II. See figure 1 and 3 .

$b$. The CTA law in general terms, see item A-III of Part III, should permit a degree of federal control over these services, because of their war potential, which may vary as in a-1 above.

c. The CTA regulations under the CTA law should specify:

1. That the large common CTA laboratories, structures, aerodynamics, motors, etc, which are built to serve several institutes, the CTA airport and its industrial facilities and the common CTA services, hotel, hospital, transportation, etc., excluding the services under committee administration listed in D-II of appendix II and delegated to the director general, see also Figures 1 and 3 .

2. That all projects in the laboratories and all projects of professional grade in the industrial and airport facilities of the CTA, must come through the institute directors and must be supported under institute contracts for research and development, see item s-I-a-2, below. 
3. That the director general present to the CTA Board annually:

(a) The basic budgets of these services,

(b) The annual reports on these services.

4. That the director general maintains under his charge, supplementary budgets for those services and activities which involve current receipts and expenditures subject to inspection by the Board.

5. That particular sections, facilities or equipment at one of the common laboratories or at the airport which are permanently assigned to one of the institutes, for example to the ITA for laboratory instructions, should be maintained under the basic or supplementary budget of the institute to which they are assigned.

6. That self-sustaining services at the CTA (which have no basic budgets), such as the reembolsável, should:

(a) Obtain a formal concession or permit from the Board,

(b) Maintain adequate accounts subject to the inspection of the Board,

(c) Maintain the grounds and building which they occupy.

7. The items on the research and development policy of the CTA which appear in section $\mathrm{D}$ below.

8. That the specific administrative powers of the Board over these common services, which are listed in D-II of appendix II, be delegated to the Director general of the CTA with instructions to modulate these powers from medium in times of peace to virtually full military in times of war, depending upon the need.

(a) Abuse of administrative powers delegated by the Board to the director general, under the CTA regulations, should be made sufficient grounds for unseating, see item A-I-b-3 above.

\section{V - The IMAS for military research and development.}

a. Degree of effective federal control, see appendix II:

1. High in times of peace to virtually full military control in times of war, depending upon the need, through a modulation of the director general's control over items E-II of appendix II, see Figures 1 and 3. 
b. The CTA law in general terms, see item A-III of Part III, should permit the degree of federal control over this institute recommended in a-1 above.

c. The CTA law, in specific terms, should require the CTA Board to create and activate a CTA military institute of research and cooperation within a period of three years after the enactment of the CTA law, whose function would be:

1. To meet the military needs of the Brazilian government for professional assistance and cooperation in a way equivalent to the way in which Wright Field and similar centers in the U.S.A. meet the needs of the U.S. Air Force.

2. To assume joint responsibility with the civilian institute of research and development for promoting the development, modernization and adequacy of Brazilian aviation and its industries and airport facilities generally. See items III-b-2 and III-c above.

d. The CTA regulations, under the CTA law, should:

1. Require the CTA Board to inform the director of the military institute on:

(a) The maximum basic budget which the Board can recommend for the institute,

(b) The maximum new construction and new equipment which the basic budget can support.

2. Require the institute director to present to the Board annually:

(a) The basic budget of the institute,

(b) The institute annual report and recommendations.

3. Require the institute director to maintain a supplementary budget for receipts and expenditures under institute contracts for research and development and to permit their inspection by the Board, see item D-I-b below.

4. Contain the general recommendations and the basic principles and policy of CTA research and development given in section D below. 
5. Delegate the specific administrative powers of the Board over the institute, which are listed in E-II of appendix II, to the director general of the CTA with instructions to modulate those powers from high in times of peace to virtually full military in times of war, depending upon the need.

(a) Abuse of administrative powers delegated by the Board to the director general, under the CTA regulations, should be sufficient grounds for unseating. See item A-I-b-3 above.

D - Research and Development Policy at the CTA.

\section{I - Policy with respect to institutional research and development}

a. The basic policy of the CTA with respect to CTA institute research and development services for industry and commerce and for the federal and state governments should be specifically written in the CTA regulations. The statement of this policy should specify at least that:

1. Institute contacts through active research and cooperation in the frontier problems in science and engineering and with the current practical problems in commerce and industry, is recognized as necessary in order to:

(a) Permit the CTA to render maximum service,

(b) Justify the existence of the CTA,

(c) Attract and retain at the CTA the best caliber men,

(d) Train professional men effectively at the ITA,

(e) Open the best placement opportunities for ITA graduates.

2. All research, testing and development work at the CTA which requires funds, must be done under specific contracts with the CTA institutes, and that:

(a) All new equipment which is installed to carry out a given research or development project, and which is purchased from that project account, should:

[1] Belong to the department which does the work if the equipment is mobile, 
[2] Belong to the laboratory in which the work was done, if the equipment is fixed.

(b) Full accounting should be kept of all charges against each research account, by the finance officer of the institute in which the work was done, and:

[1]Disbursement should be made simply on the order of the department head concerned.

[2] Balances should be spent by the same department head, in the interest of the department, without formality.

3. All property rights to the results of CTA research and development, which are done under non-government contracts, belong to:

(a) The contract during the first three years,

(b) To the public after the first three years,

[1] Unless a longer period is specified for good cause in the original contract.

(c) The purpose of item 3 is to stimulate the contracted to apply new results and to prevent him from freezing progress by permanently withholding application of a new advance in science or technology.

4. All unrestricted research and development which is published by the CTA, should be published in one common CTA journal or report series or both.

(a) This regulation would centralize all CTA publications in one or two sources (just as the CTA itself centralizes all razilian professional aeronautics in one organization).

(b) This regulation would also load to an earlier international recognition of CTA publications.

5. All permanent, basic budget, personnel at the CTA institutes of research and development must be appointed on full time appointments, which:

(a) Are coordinated in salary and rank with the staff of the ITA,

(b) Give the same opportunities for private consulting and professional practice outside the CTA as are given to the staff of the ITA. 
II - Policy with respect to private research and development for which no budget funds are required, and with respect to private consulting and professional practice outside the CTA, should also be specifically written in the CTA regulations. These provisions should specify that:

a. Private research by permanent, basic budget, personnel in any of the CTA institutes for which no budget funds are required is recognized as good policy and worthy of government encouragement because it:

1. Is the most effective way in which the Brazilian government can subsidize fundamental research. Basic research which is done by permanent men under basic budgets of the CTA actually is research done under $100 \%$ decentralization of federal control. This degree of decentralization is correct for the best results, (compare for example German and French research in Part I and appendix I).

2. Attracts to the CTA the best men, keeps them up-to-date and professionally contented.

3. Very often it is the genesis of important advances in technology which give the country which discovers them an important military or industrial advantage.

b. Private consulting and private professional practice by basic budget staff members of the CTA outside the CTA is recognized as good policy and worthy of government encouragement, provided:

1. Neither the educational nor the research and development programs at th CTA are adversely affected,

2. The amount and character of the outside contacts strengthen the usefulness of the staff men at the CTA.

3. The work is not done on CTA time nor with CTA facilities.

III - Policy witch respect to coordinate institutional research at the CTA and at other institutions, where a division of funds and fields may be required, should be specifically covered in the CTA regulations. These provisions should specify that: 
a. The institution which initiates the joint project should contract to do the whole project and:

1. Sub-contract the cooperating institution to do its part of the project, under the following conditions:

(a) The initiating institution has the rights of publication of the whole project, if the matter is unrestricted,

(b) The initiating institution has the responsibility of secrecy over the whole project, if the matter is restricted.

E - Educational Policy at the CTA.

I - The CTA law, in specific terms, should state that all publications, echnical reports, certificates, atestados, diplomas, issued and granted by the CTA should be honored in all Brazil for all purposes as if granted by the government itself.

II - The CTA law, in specific terms, should require that the ITA institute for education and fundamental research:

a. Be organized under a normal board-reitor-corpo docente type of university organization which has proven its correctness in a hundred years of application in hundreds of American universities and technical schools, and under which:

1. The board deals only with the reitor and exercises no administrative powers at levels below the reitor, see Figures 1 and 3 and item A-IIIa of Part III.

2. The board holds the legal powers of the CTA and the CTA has the legal status of a private, independent, non-profit, research and educational foundation whose basic budgets are covered by the government, see items A-I, A-II and C-III of Part III.

b. Consist of two separate schools:

1. An escola fundamental for the basic physical sciences and their associated disciplines, 
2. An escola profissional for the application of the basic physical sciences and their associated disciplines to all of the main professional fields in science and engineering upon which aeronautics depends for professional men and research, and leading to professional degrees in these fields, and including:

(a) A graduate school leading to higher degrees in these fields including the doctorate.

c. Appoint men to the permanent staff, (under the support of the basic budget), only on full time appointments.

d. Subsidize students as specified in item E-III-b, below.

III - The CTA regulations, under the CTA law, should further specify that:

a. The fundamental and professional schools above be two separate schools each with its own staff and educational plant and with its own rules and regulations, and that:

1. The escola fundamental be made responsible for preparing Brazilian high school students to enter applied courses at the ITA, or at any other engineering school in engineering and economics, at the beginning third university year level and should terminate:

(a) With voluntary career fitness and vocational guidance examinations and conferences,

(b) Certificates of competence in the basic physical science fields which signify:

[1] Satisfactory professional orientation,

[2] Satisfactory integrity,

[3] Satisfactory subject coverage.

2. The escola profissional be made responsible for teaching the graduates of the escola fundamental how to apply what they know in the various professional fields upon which aeronautics depends and:

(a) After three years of university grade study should grant the bachelors degree in field, 
(b) After four years of university grade study school grant the masters degree in field,

(c) After six years of university grade study normally, should grant the doctors degree in field.

b. The federal aid to students under item D-V of Part III shall provide:

1. In the case of native civilian students:

(a) Free tuition, board and room,

(b) Free medical and dental care,

(c) Free access to the ITA laboratories, library and athletic facilities, (no fee system),

(d) Free official travel, covering:

[1] Initial travel to the point of entrance examination and to the ITA at the beginning of the course,

[2] Field trips connected with the study program,

[3] Final travel from the ITA at the end of the course.

(e) A small monthly allowance for incidentals.

2. In the case of native military students:

(a) For items (a), (b), (c) and (d) -(2) above,

3. In the case of foreign students:

(a) Tuition, board and room at half cost,

(b) For items (b), (c) and (d)-(2) above.

c. The following foreign relations may be negotiated by the CTA:

1. Profissional and técnico especializado exchange program between the CTA and recognized universities, technical schools and research centers abroad:

(a) In which case the CTA man abroad will draw his full CTA salary and half his travel expenses during the exchange.

[1] Charged against the basic budget of the institute concerned.

2. Foreign scholarships for a limited number of outstanding ITA graduates and of CTA staff men in which cases:

(a) Full living and travel expenses would be paid. 
[1] Under the basic budget of the institute concerned,

[2] To the number of men allowed in the basic budgets of the CTA institutes.

$d$. The ITA cannot grant honorary degrees.

1. The reason for this restriction is the following.

Eminence in the physical science and engineering fields cannot be attained, except in exceedingly rare cases, outside formal training in the right disciplines. Eminence in the social sciences, education, literature, arts, diplomacy can be obtained, and often is obtained, outside formal study and when so attained may properly be recognized by an advanced honorary degree.

$\mathbf{F}$ - Inter-institute relations within the CTA.

I - The CTA regulations, under the CTA law, should:

a. Establish the coordinate status of the several institutes of the CTA and of their administrative and professional staffs and should specify that all institutes are equally dependent upon the CTA Board for their:

1. Basic budgets,

2. Buildings, facilities and general services.

b. Permit dual staff appointments in two institutes under the following conditions (see item B of the original "Basic Policy and Plan" for the CTA).

1. On the mutual agreement of two institute directors, and in the case of the ITA on the approval of the congregação if necessary, the department headships in two institutes may be hold by the same man, in which case, of the ITA on the approval of the congregação if necessary, the department headships in two institutes may be hold by the same man, in which case,

(a) The department head would be administratively responsible in non-technical matters, to the director in whose institute he was first appointed. 
(b) A $25 \%$ gratification would be added to the salary.

2. When department headships in two departments in different institutes are hold by the same man, and when he recommends it:

(a) Associateships in the same two departments may be held by the same man,

(b) When dual appointments are made at the associate level, no gratification should be added to the salary.

3. Dual appointments at the assistant professor level and below should be specifically disallowed.

4. All dual appointments should be temporary.

c. Joint use of the common facilities, laboratories and services by the several institutes should be adjudicated by the director general of the CTA under his normal powers, see item D-II, appendix II. 


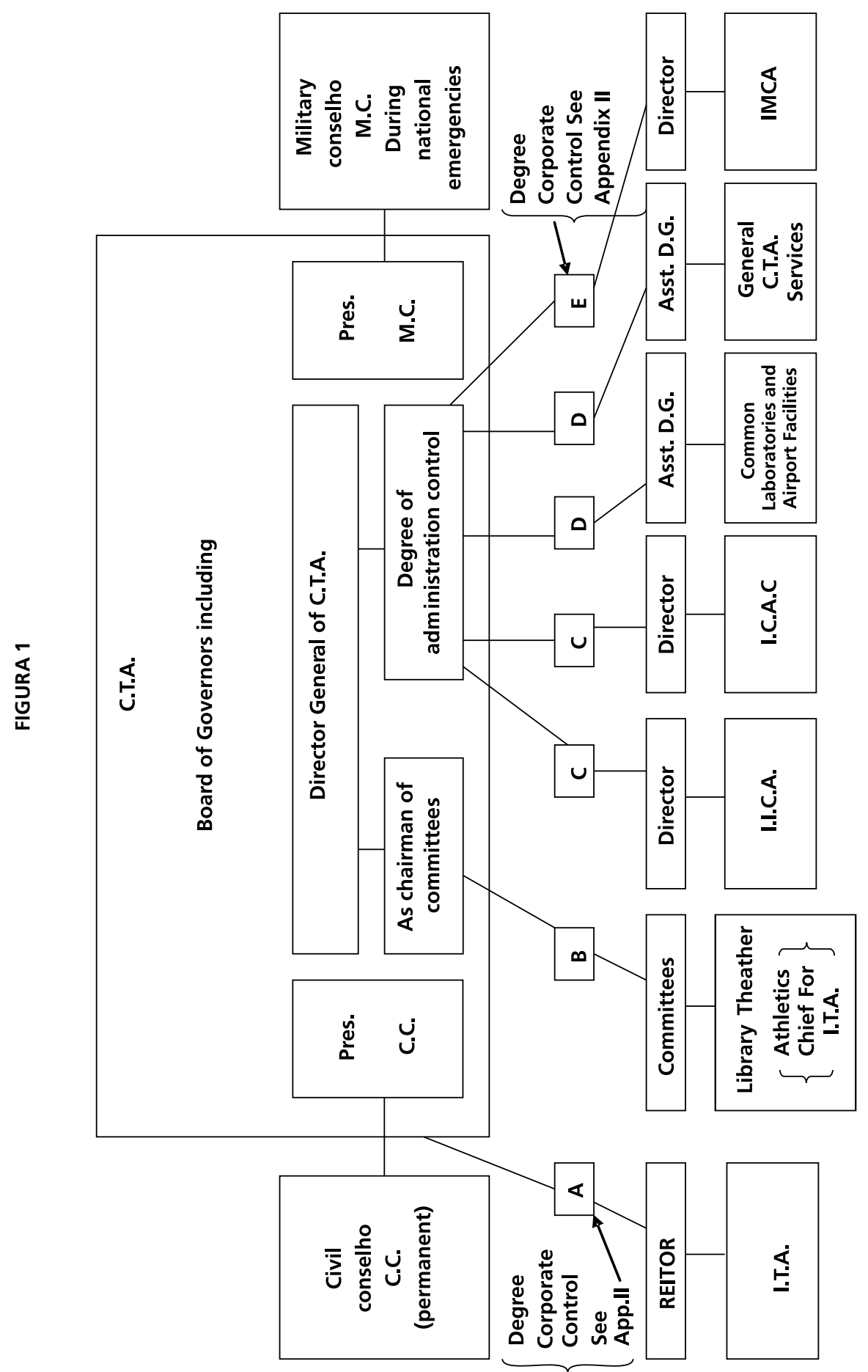




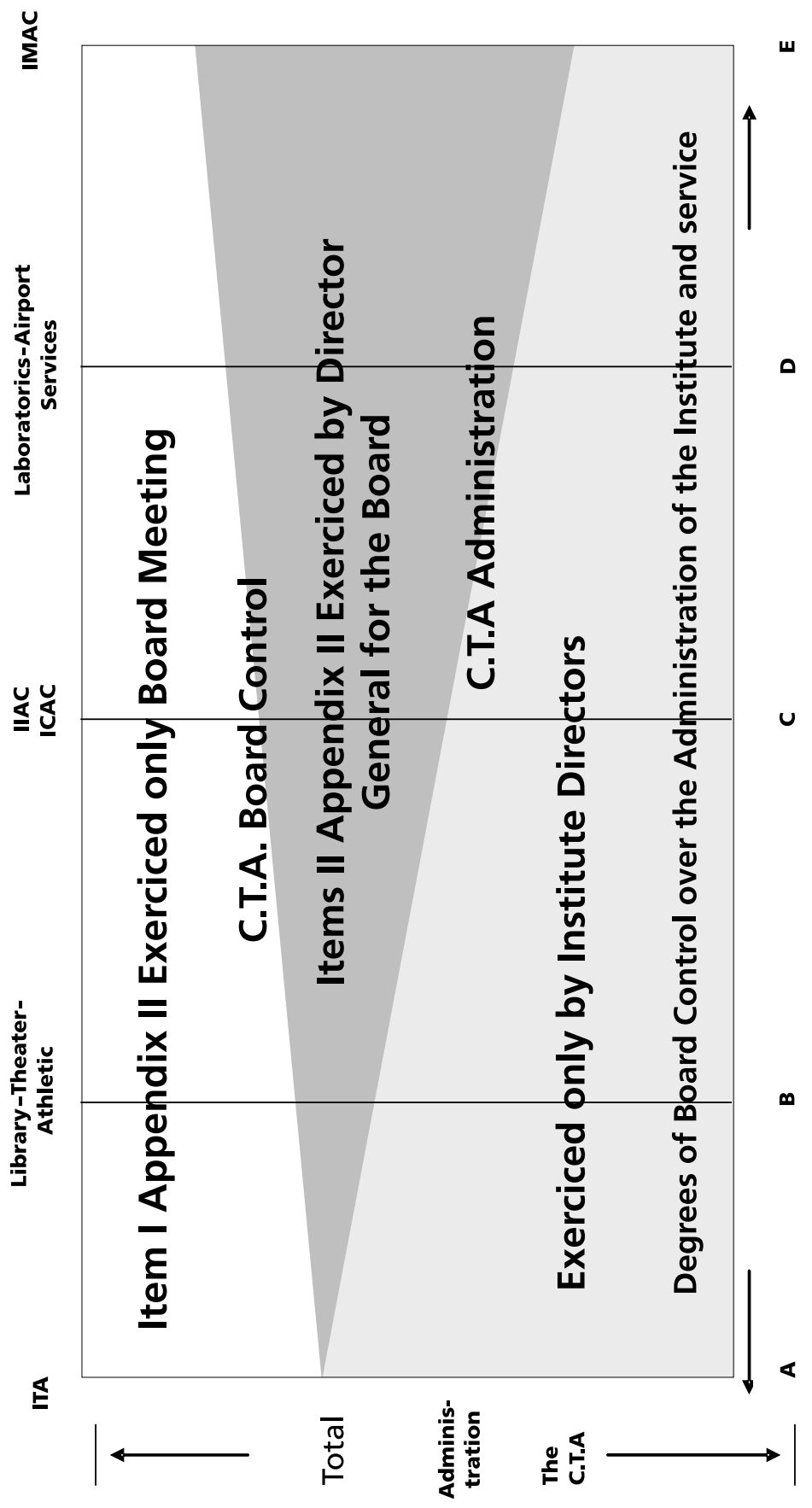

